life and the first part of pupal were passed in a damp jar (March 30 to April 5). The imago is nevertheless a characteristic example of the dry phase.

Fig. 3. Precis antilope + , form simia, Salisbury, 5000 feet, captured

Feb. 23, 1902, after it had laid eleven eggs. Parent of butterflies represented in Figs $3 a$ and $3 b$. The underside is shown on Plate XIII, fig. 4.

3a. Precis antilope + , offspring No. 1 of butterfly represented in Fig. 3. Egg laid Feb. 23, hatched March 1, larra pupated April 10, imago emerged April 27. The under-side is shown on Plate XIII, fig. $4 a$.

3b. Precis antilope $\mathcal{o}^{\mathrm{N}}$, offspring No. 2 of butterfly represented in Fig. 3. Egg laid Feb. 23, hatched March 1, larva pupated April 14, imago emerged April 29. The underside is shown on Plate XIII, fig. $4 b$.

4. Frecis archesia 9 , captured Oct. 7, 1897, at Malvern, 800 feet, near Durban, Natal. This insect was in coitu with the form represented in Fig. 5.

5. Precis archesia of, a form varying somewhat distinctly in the direction of the wet phase (pelasgis), captured in coitu with the insect represented in Fig. 4. The tendency towarls pelasgis is better shown upon the under-side, Plate XIII, fig. 8 .

\title{
Explanation of Plate XIII.
}

\section{Seasonal Phases of Butterfies of the Genus Precis.}

Under-sides of seasonal phases of Precis sesamus, P. antilope, and $P$. archesia, including those of $P$. antilope and its two offspring shown on Plate XII.

All the figures are about $\frac{9}{10}$ of the natural size.

All the specimens not otherwise described were captured by Guy A. K. Marshall.

FIG. 1. Precis sesamus, form natalensis $q$, under-side of wings; Salisbury, 5000 feet, captured Feb. 20, 1898. Comparing this with Figs. $1,1 b$, and 2 on Plate XII, it is seen that the under-side, although very similar to the upper, is even more conspicuous than it. The difference is brought about by the pale spots on the black basal patch of the 
hind-wings and the more distinct white markings in the black marginal band, on the under-side; also by the paler tint of the ground-colour, making a stronger contrast with the black markings.

FIG. 2. Precis sesamus $q$, under-side of wings; Salisbury, 5000 feet, captured April 2, 1898. Even in the absence of colour the astounding difference between this and the wet-season phase (see Fig. 1) is clearly shown.

3. Precis sesamus, form natalensis of, strongly tending towards the dry phase, under-side of wings; Machakos, British East Africa, captured June 6, 1900, by Mr. and Mrs. S. L. Hinde. This beautiful variety stands well on the wet, or red, side of intermediate.

4. Precis antilope, form simia + , under-side of wings ; Salisbury, Feb. 23, 1902. Parent of butterflies represented in Figs. $4 a$ and $4 b$. This figure shows the under-side of the specimen represented in Fig. 3, Plate XII. It is seen that the under-side is much more conspicuous than the upper in the points mentioned above in the description of P. sesamus, form natalensis (Fig. 1); especially in the far greater contrast between the lighter ground-colour and the black markings and in the amount of white in the black border.

4a. Precis antilope + , under-side of wings. Offspring No. 1 of butterfly represented in Fig. 4. This figure shows the under-side of the butterfly represented in Fig. $3 a$, Plate XII. The difference between the under-side in offspring and parent is as astonishing as in the two phases of sesamus, while the difference in shape of the wings is even more remarkable.

4b. Precis antilope ${ }_{0}^{+}$, under-side of wings. Offspring No. 2 of butterfly represented in Fig. 4 . This figure shows the under-side of the butterfly represented in Fig. 3b, Plate XII. The great difference in the character of the underside in the two offspring (compare this figure with the preceding) is well shown, although both represent dead leaves equally well.

5. Precis archesia, form pelasgis ô, under-side of wings ; Salisbury, 5000 feet, captured Dec. 11, 1897. The figure shows well that the difference between the two phases of this species is far more important upon the under-than the upper-side. It is also seen that the pale, conspicuous, sharply-outlined, black-spotted band of the wet phase represents the intensely cryptic mid-rib-like streak of the 
dry phase (compare this figure with Figs. 6, 7, and the somewhat intermediate Fig. 8).

FIG.6. Precis archesia of, under-side of wings ; Salisbury, 5000 feet, captured April 30, 1899. The mottled browns and greys of the under-side are very markedly different from the uniform dark brown of the wet phase. Great variation in these mottled tints occurs in different individuals, harmonizing with the varied appearance of rocks, being at the same time dead-leaf-like.

7. Precis archesia + , under-side of wings; Berea, near Durban, Natal, captured April 5, 1896, by Mr. D. Chaplin. In this variety of archesia the ground-colour is comparatively unmottled, and to this extent transitional towards the pelasgis form. This difference upon the under-side corresponds with a slight approach in the same direction on the upper-side, where the deep red-brown band is broader and more continuous than is usual in typical archesia.

8. Precis archesia of, under-side of wings ; variety distinctly transitional towards the pelasgis (wet) phase ; Malvern, 800 feet, near Durban, Natal. This specimen was captured in coitu with a + of typical pelasgis, Oct. 7, 1897. The intermediate character is seen in the conspicuous broad light band as well as in the unmottled groundcolour. Comparing this with Figs. 5 and 6, it is seen that in spite of this distinct tendency towards pelasgis, the specimen represented in Fig. 8 is still well on the archesia side of intermediate, and would doubtless be well concealed with its wings closed. The character of the surface of both wings outside the broad band is especially unlike pelasgis, as is the gradual transition of the outer border of the band itself into the ground-colour. The upper-side of the specimen here represented is shown on Plate XII, fig. 5 , and that of the $q$ pelasgis with which it was in coitu on Plate XII, fig. 4. 


\section{$2 \mathrm{BHL}$ Biodiversity Heritage Library}

1902. "Explanation of Plate XIII." Transactions of the Entomological Society of London 50, 557-559. https://doi.org/10.1111/j.1365-2311.1902.tb02432.x.

View This Item Online: https://www.biodiversitylibrary.org/item/48243

DOI: https://doi.org/10.1111/j.1365-2311.1902.tb02432.x

Permalink: https://www.biodiversitylibrary.org/partpdf/25284

\section{Holding Institution}

Smithsonian Libraries

\section{Sponsored by}

Smithsonian

\section{Copyright \& Reuse}

Copyright Status: Public domain. The BHL considers that this work is no longer under copyright protection.

This document was created from content at the Biodiversity Heritage Library, the world's largest open access digital library for biodiversity literature and archives. Visit BHL at https://www.biodiversitylibrary.org. 